\title{
Biodiversity of benthic macroinvertebrates on hard substrates in the Currais Marine Protected Area, in southern Brazil
}

\author{
Janaína Bumbeer ${ }^{1,2 *}$, André Pereira Cattani ${ }^{2}$, Nícolas Binneck Chierigatti ${ }^{3}$ \& Rosana Moreira da Rocha ${ }^{3}$ \\ ${ }^{1}$ Universidade Federal do Paraná, Caixa Postal 19031, CEP: 81531-980, Curitiba, PR, Brazil \\ ${ }^{2}$ Associação MarBrasil, Av. Beira-Mar, s/n, Caixa Postal 48, CEP 83255-976, Pontal do Paraná, PR, Brazil \\ ${ }^{3}$ Universidade Federal do Paraná, Departamento de Zoologia, Caixa Postal 19020, CEP 81531-980, Curitiba, PR, Brazil \\ *Corresponding author: Janaina Bumbeer, e-mail: janabumbeer@gmail.com
}

BUMBEER, J., CATTANI, A.P., CHIERIGATTI, N.B., ROCHA, R.M. Biodiversity of benthic macroinvertebrates on hard substrates in the Currais Marine Protected Area, in southern Brazil. Biota Neotropica. 16(4): e20160246. http://dx.doi.org/10.1590/1676-0611-BN-2016-0246

\begin{abstract}
This study describes the biodiversity of benthic invertebrates on hard substrates in the Currais Marine Protected Area (Currais MPA), in the state of Paraná. The benthic community was sampled during 2012 to 2015, in winter and summer, at two islands and four groups of artificial reefs (ARs). Samples were collected along shallow (2-4 m) and deep (6-8 $\mathrm{m})$ transects at the islands and $\sim 18 \mathrm{~m}$ transects at the ARs. We also searched the literature to review all published records of benthic invertebrates on hard substrates in the Currais MPA. We recorded 176 taxa in the phyla Annelida (class Polychaeta), Arthropoda (class Maxillopoda, order Sessilia), Bryozoa, Cnidaria, Chordata (class Ascidiacea), Echinodermata, Mollusca and Porifera, in 13 classes, 40 orders and 75 families. With these 102 new records, our list comprises $58 \%$ of all recorded species. Of these, 58 taxa were first records for the state of Paraná. This remarkable number of new records highlights that biodiversity studies are lacking in Paraná. Fifteen non-indigenous species and one endangered species, the sea star Coscinasterias tenuispina (Lamarck, 1816), are included. This is an important transitional area to monitor expansion or constriction of the latitudinal distributions of species, in the context of climate change, that may influence the geographical distribution of species (both native and invasive). This study is the first inventory of marine hard substrate habitats of the Currais MPA with a surprisingly diverse community.
\end{abstract}

Keywords: benthic invertebrates, exotic species, inventory, marine conservation, Paraná coast.

\section{Biodiversidade da comunidade bêntica de ambientes rochosos na Área Marinha Protegida de Currais, sul do Brasil.}

\begin{abstract}
Resumo: Este estudo descreve a biodiversidade da comunidade de invertebrados bênticos de ambientes rochosos da Área Marinha Protegida de Currais (AMP Currais), localizada no estado do Paraná. A comunidade bêntica foi amostrada entre 2012 e 2015, durante períodos de inverno e verão, em duas ilhas e quatro grupos de recifes artificiais (RAs). As amostras foram obtidas em transecções rasas (2-4 m) e mais profundas (6-8 $\mathrm{m}$ ) nas ilhas e a $\sim 18 \mathrm{~m}$ nos RAs. Também foi realizada uma pesquisa bibliográfica para examinar todos os registros de invertebrados bênticos publicados para a área da AMP Currais. Foram encontrados 176 táxons pertencentes aos filos Annelida (classe Polychaeta), Arthropoda (classe Maxillopoda, ordem Sessilia), Bryozoa, Cnidaria, Chordata (classe Ascidiacea), Echinodermata, Mollusca e Porifera, distribuídos em 13 classes, 40 ordens e 75 famílias. Há 102 novos registros para a área, representando 58\% de todas as espécies registradas. Destes, 58 táxons não haviam sido registrados anteriormente no estado do Paraná. Este notável número de novos registros revela a falta de estudos sobre a biodiversidade no litoral do Paraná. Quinze espécies exóticas foram encontradas, e uma espécie em extinção, a estrela-do-mar Coscinasterias tenuispina. Esta é uma importante área de transição para acompanhar a expansão ou constrição da distribuição latitudinal das espécies, considerando as alterações climáticas que poderão influenciar na distribuição geográfica das espécies (tanto nativas quanto invasoras). O presente estudo constitui o primeiro inventário dos habitats de substrato rochoso da AMP Currais e revela grande biodiversidade.
\end{abstract}

Palavras-chave: invertebrados bênticos, espécies exóticas, inventário, conservação marinha, litoral do Paraná. 


\section{Introduction}

The National Marine Park of Currais Islands is a new Marine Protected Area (MPA, hereafter Currais MPA) that was created in 2013 (Brazilian federal law number 12.829, Brasil 2013). It is the first MPA in the category National Marine Park in the state of Paraná and the third in Brazil (the other two are Abrolhos and Fernando de Noronha, both in northeastern Brazil). Currais MPA is in an area of large economical and ecological importance, because of a major commercial port with international traffic of container ships and oil tankers and because of the extensive system of estuaries with mangroves. The creation of the Currais MPA was based on its importance for seabird breeding (Krul 2004, Carniel \& Krul 2010). Previous studies of the marine environment tended to focus on the ichthyofauna (Félix \& Harckradt 2008, Félix-Hackradt \& Hackradt 2008, Harckradt \& Félix-Harckradt 2009, Daros et al. 2012). Only one study examined the soft bottom infauna (Lorenzi \& Borzone 2009), three examined benthic invertebrates on hard substrates, one of ascidians (Rocha \& Faria 2005) and two experimental studies on temporal colonization of artificial substrates near the islands (Brandini \& Silva 2011, Bumbeer \& Rocha 2012). Since the creation of the MPA, there has been only one study of marine biota, which examined the algal community (Pellizzari et al. 2014). On a larger scale, invertebrates of hard substrates are very poorly studied along the entire coast of Paraná, and is a major gap in the understanding of species distributions in Brazil.

Hard substrates such as those typically present around coastal islands, rocky shores and calcareous bottoms are uncommon in coastal Paraná. Thus, Currais MPA is ecologically relevant for its hard substrate for communities adapted to reef-like habitats, and because it is less impacted as nearer the mainland. Also, Currais islands was at one time (prior to creation of the MPA) an important area for both recreational and artisanal fisheries and also the main site for recreational scuba diving in Paraná. The Currais MPA is also under the influence of continental drainage from the Paranaguá Estuarine Complex, with anthropogenic impact that potentially threatens local biodiversity, such as contamination by urban and industrial development (Noernberg et al. 2008, Possatto et al. 2014) and bioinvasions (Bumbeer $\&$ Rocha 2016). Indeed, the presence of a large port with its ship traffic probably favors the spread of non-indigenous species (NIS) to the open coastal environment, including Currais MPA (Bumbeer \& Rocha 2016).

Understanding the benthic communities on hard substrates is critical because this environment has been heavily disturbed by human activities, potentially leading to decline in biodiversity and to irreversible loss of biological information. Despite this importance, three years after its establishment, no management plan has been developed for MPA Currais. During the same time interval, development on the mainland has been growing rapidly, including the construction of a new port for containers that will increase by $55 \%$ the port capacity in the state and is scheduled to start activities in 2018 (http://portopontal.com.br). Therefore, in this scenario it is clear that establishing baselines of community composition and distribution on all types of habitats is very important within MPA Currais, including benthic communities, in order to monitor and understand future changes. Here we provide the first inventory of the benthic macroinvertebrate species on hard substrates of the Marine Protected Area of Currais, including the sessile community and sedentary vagile organisms (i.e., Gastropoda, Polychaeta and Echinodermata).

\section{Material and Methods}

The National Marine Park of Currais Islands is located 6.2 miles from the coast, between two estuaries, Guaratuba Bay and the Paranaguá Estuarine Complex (Figure 1). With a total area of 1400 ha, the MPA includes three islands (Grapirá, Três Picos and Filhote) and four groups of artificial reefs (ARs) (concrete blocks placed on the seabed to provide new environments for encrusting communities). The depth along the archipelago varies from 1.5 to $16 \mathrm{~m}$, with natural hard substrates usually up $10 \mathrm{~m}$. The inclination of the rocky shores is moderate, between $45^{\circ}$ and $60^{\circ}$ (Daros et al. 2012). The artificial reefs were placed in 1997 on the sandy bottom at a depth around $18 \mathrm{~m}$.

The benthic community was sampled at two islands, Grapirá and Três Picos, and four ARs. Sites of different depth and wave exposure were sampled to include a wider variety of environmental conditions. At each island, two sites were chosen, one exposed to the open sea and another sheltered from the main wave train by the island. Each of the four sites
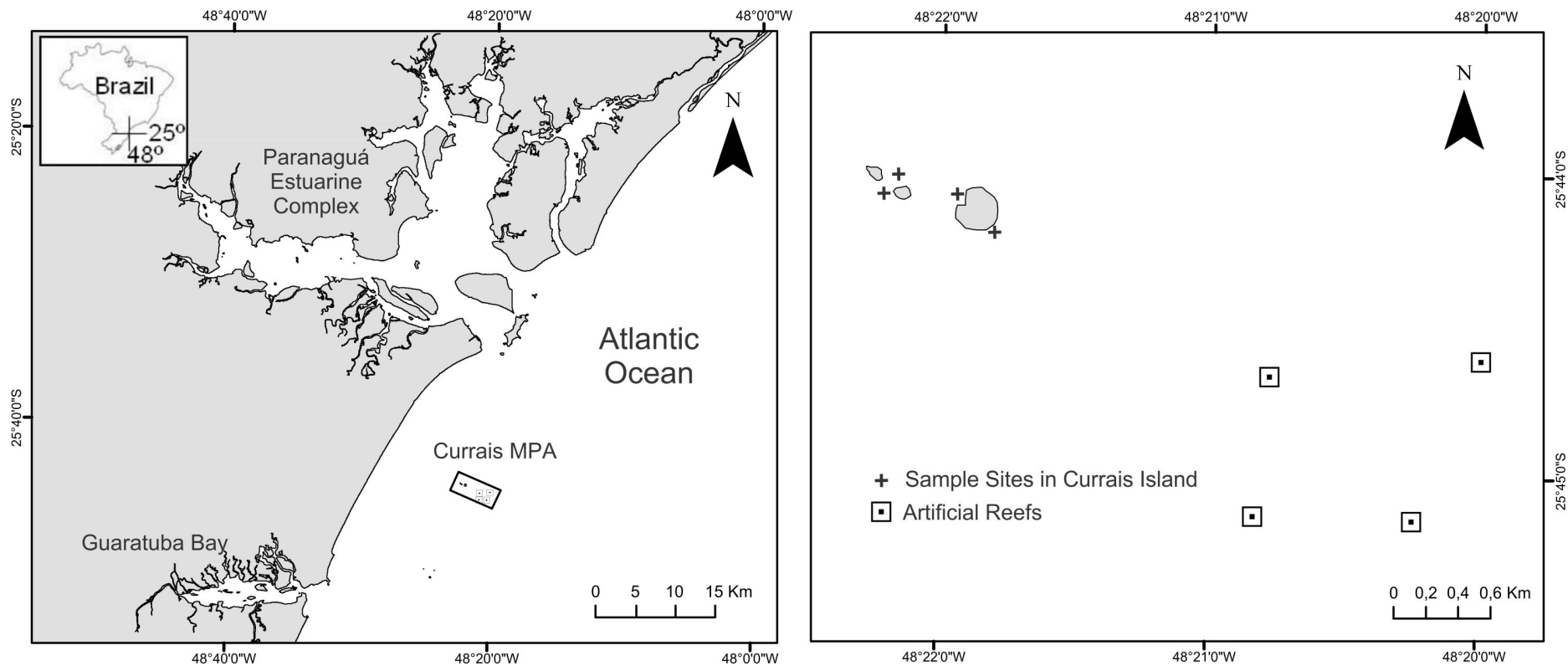

Figure 1. The Marine Protected Area of Currais Islands and the sampling sites. Left: the location and area of the MPA in the Paraná coast. Right: detail of the sampling sites inside the MPA. 
were surveyed in shallow (around $2-4 \mathrm{~m})$ and deep $(6-8 \mathrm{~m})$ transects, while artificial reef sites were surveyed in two transects at $\sim 18 \mathrm{~m}$ (Table 1).

Sites were sampled during 37 SCUBA dives, between July 2012 and January 2015 (Table 1), during summer and winter to include possible seasonal variation in abundance of species. During dives, we actively searched for all relevant species within the area of the transect $(20 \mathrm{~m}$ long vs. $2 \mathrm{~m}$ wide), photographed and individuals and colonies were manually collected for identification. Horizontal, vertical and negative surfaces were sampled, as well as crevices and under rocks. Upon collection, samples were treated with a menthol solution in seawater for relaxation of the fauna and were subsequently fixed in $4 \%$ formalin for taxonomical study by specialists. The Mollusca were deposited in the Zoology Museum of University of São Paulo (MZUSP), Porifera in the National Museum of University of Rio de Janeiro (MN-UFRJ), Cnidaria and Tunicata in the collection of the Zoology Department of the Federal University of Paraná (DZUP).

Table 1. Number of transects and collecting dates (in day/month/year format) per sampling site.

\begin{tabular}{|c|c|c|c|}
\hline Sampling Sites & Coordinates & Date & $\begin{array}{c}\text { \# of } \\
\text { Transects }\end{array}$ \\
\hline \multicolumn{4}{|l|}{ Currais Islands } \\
\hline \multirow{6}{*}{ Grapirá Exposed } & $25^{\circ} 44^{\prime} 06^{\prime \prime} \mathrm{S}, 48^{\circ} 21^{\prime} 59^{\prime \prime} \mathrm{W}$ & $24 / 07 / 2012$ & 2 \\
\hline & & $18 / 12 / 2012$ & 2 \\
\hline & & 06/06/2013 & 2 \\
\hline & & $17 / 12 / 2013$ & 2 \\
\hline & & 26/06/2014 & 2 \\
\hline & & 08/01/2015 & 2 \\
\hline \multirow[t]{6}{*}{ Grapirá Protected } & $25^{\circ} 44^{\prime} 04^{\prime \prime} \mathrm{S}, 48^{\circ} 21^{\prime} 50^{\prime \prime} \mathrm{W}$ & 24/07/2012 & 2 \\
\hline & & $18 / 12 / 2012$ & 2 \\
\hline & & 06/06/2013 & 2 \\
\hline & & $17 / 12 / 2013$ & 2 \\
\hline & & 26/06/2014 & 2 \\
\hline & & $08 / 01 / 2015$ & 2 \\
\hline \multirow[t]{6}{*}{ Três Picos Exposed } & $25^{\circ} 44^{\prime} 06^{\prime \prime} \mathrm{S}, 48^{\circ} 22^{\prime} 16^{\prime \prime} \mathrm{W}$ & 24/07/2012 & 2 \\
\hline & & $18 / 12 / 2012$ & 2 \\
\hline & & $06 / 06 / 2013$ & 1 \\
\hline & & $17 / 12 / 2013$ & 2 \\
\hline & & $26 / 06 / 2014$ & 2 \\
\hline & & 08/01/2015 & 2 \\
\hline \multirow[t]{6}{*}{ Três Picos Protected } & $25^{\circ} 44^{\prime} 01^{\prime \prime} \mathrm{S}, 48^{\circ} 22^{\prime} 13^{\prime \prime} \mathrm{W}$ & $24 / 07 / 2012$ & 2 \\
\hline & & $18 / 12 / 2012$ & 2 \\
\hline & & 06/06/2013 & 2 \\
\hline & & $17 / 12 / 2013$ & 2 \\
\hline & & 26/06/2014 & 2 \\
\hline & & 08/01/2015 & 2 \\
\hline \multicolumn{4}{|l|}{ Artificial Reefs } \\
\hline \multirow[t]{4}{*}{ AR1 } & $25^{\circ} 44^{\prime} 04^{\prime \prime} \mathrm{S}, 48^{\circ} 20^{\prime} 46^{\prime \prime} \mathrm{W}$ & $13 / 12 / 2012$ & 2 \\
\hline & & $13 / 02 / 2013$ & 2 \\
\hline & & $17 / 12 / 2013$ & 2 \\
\hline & & 07/01/2015 & 2 \\
\hline \multirow[t]{2}{*}{ AR2 } & $25^{\circ} 44^{\prime} 36^{\prime \prime} \mathrm{S}, 48^{\circ} 20^{\prime} 46^{\prime \prime} \mathrm{W}$ & $13 / 06 / 2013$ & 2 \\
\hline & & $17 / 12 / 2013$ & 2 \\
\hline \multirow[t]{5}{*}{ AR3 } & $25^{\circ} 45^{\prime} 08^{\prime \prime} \mathrm{S}, 48^{\circ} 20^{\prime} 14^{\prime \prime} \mathrm{W}$ & $13 / 02 / 2013$ & 2 \\
\hline & & $13 / 06 / 2013$ & 2 \\
\hline & & $17 / 12 / 2013$ & 2 \\
\hline & & $31 / 07 / 2014$ & 2 \\
\hline & & $07 / 01 / 2015$ & 2 \\
\hline \multirow[t]{2}{*}{ AR4 } & $25^{\circ} 45^{\prime} 08^{\prime \prime} \mathrm{S}, 48^{\circ} 20^{\prime} 50^{\prime \prime} \mathrm{W}$ & $13 / 12 / 2012$ & 2 \\
\hline & & $13 / 06 / 2013$ & 2 \\
\hline
\end{tabular}

A search of the literature was also conducted to review all published records of benthic invertebrates on hard substrates in the area of the Currais MPA. The species recorded on both field survey and previous studies were indicated if found in natural substrata of islands, ARs or recruitment plates. The status of bioinvasion and endangered species were also indicated according to literature and Brazilian official lists (Lopes 2009, MMA 445/14).

\section{Results}

We found 132 taxa in this survey, with 99 found on the hard substrates of the islands and 122 on artificial substrata (86 in AR and 57 in recruitment plates). Only 45 were common to both natural and artificial substrates (Table 2). Of the 132 taxa sampled, 76 were found in both winter and summer, 22 only in summer and 34 only in winter (Table 2). Currently, a total of 176 taxa, comprising the phyla Porifera, Cnidaria, Bryozoa, Mollusca, Annelida (class Polychaeta), Arthropoda (class Maxillopoda, order Sessilia), Echinodermata and Chordata (class Ascidiacea), including 13 classes, 40 orders and 75 families, have been recorded in Currais MPA (Figures 2-5, Table 2). The most common groups were Mollusca (21 bivalves and 21 gastropods), Cnidaria (13 anthozoans and 22 hydrozoans), Ascidiacea (25 taxa), Porifera (23 taxa), Polychaeta (22 taxa), Bryozoa (14 taxa), Sessilia and Echinodermata with eight taxa each.

New records $(\mathrm{n}=102)$ for the MPA area include $58 \%$ of all recorded species. Of these, 58 were not previously recorded for Paraná. Except Arthropoda, new records were found for all phyla, mainly Porifera $(n=20)$. Additionally, some species have not yet been described. Examples in Polychaeta are a Lumbrineridae (genus Lumbricalus) found at both islands and ARs and a bluish Nereididae, found only in the ARs. In the Ascidiacea, a new didemnid has a peculiar zebra-striped pattern (Didemnum sp.1), and which was previously found in the area and the neighbors states of São Paulo and Santa Catarina (R.M. Rocha, unpublished data) and a transparent Eudistoma in small colonies that were usually attached to red coralligenous algae.

Fifteen non-indigenous species were recorded, including three new records for Currais MPA: Ophiothela mirabilis Verrill, 1867, Didemnum perlucidum Monniot F., 1983 and Myoforceps aristatus (Dillwyn, 1817) (also known as Lithophaga aristata and Leisolenus aristatus). Also, one endangered sea star Coscinasterias tenuispina (Lamarck, 1816) is considered vulnerable by the most recent statement of the Environmental Ministry (MMA 445/14).

\section{Discussion}

In this first comprehensive list of the benthic invertebrates on hard substrates of the Currais MPA, many species first records for the state of Paraná. Previous reports of the biodiversity of Currais MPA were superficial and so as a consequence, our field survey increases by $58 \%$ the number of species found there. Some of these new records had been found in the neighbor states of São Paulo and Santa Catarina, and so were not surprising.

Most bryozoans have taxonomic issues to be solved before being able to identify species. The unidentified ascidians are new species in the process of being described in our lab. Diplosoma sp., however, will require further sampling in order to identify the species. Some polychaetes are new species, while features to identify some others are lacking. Many sponges are difficult to identify without extensive study of internal anatomy, for which more samples are needed. Thus, 32 taxa remain unidentifiable, which further emphasizes the importance of continued studies in this region.

The differences between taxa found at the islands on natural substrates and those found on artificial substrates were not very surprising. Artificial reefs of concrete to attempt mimicking the natural substrate still have different shapes and textures and they were simply laid on the seabed at 


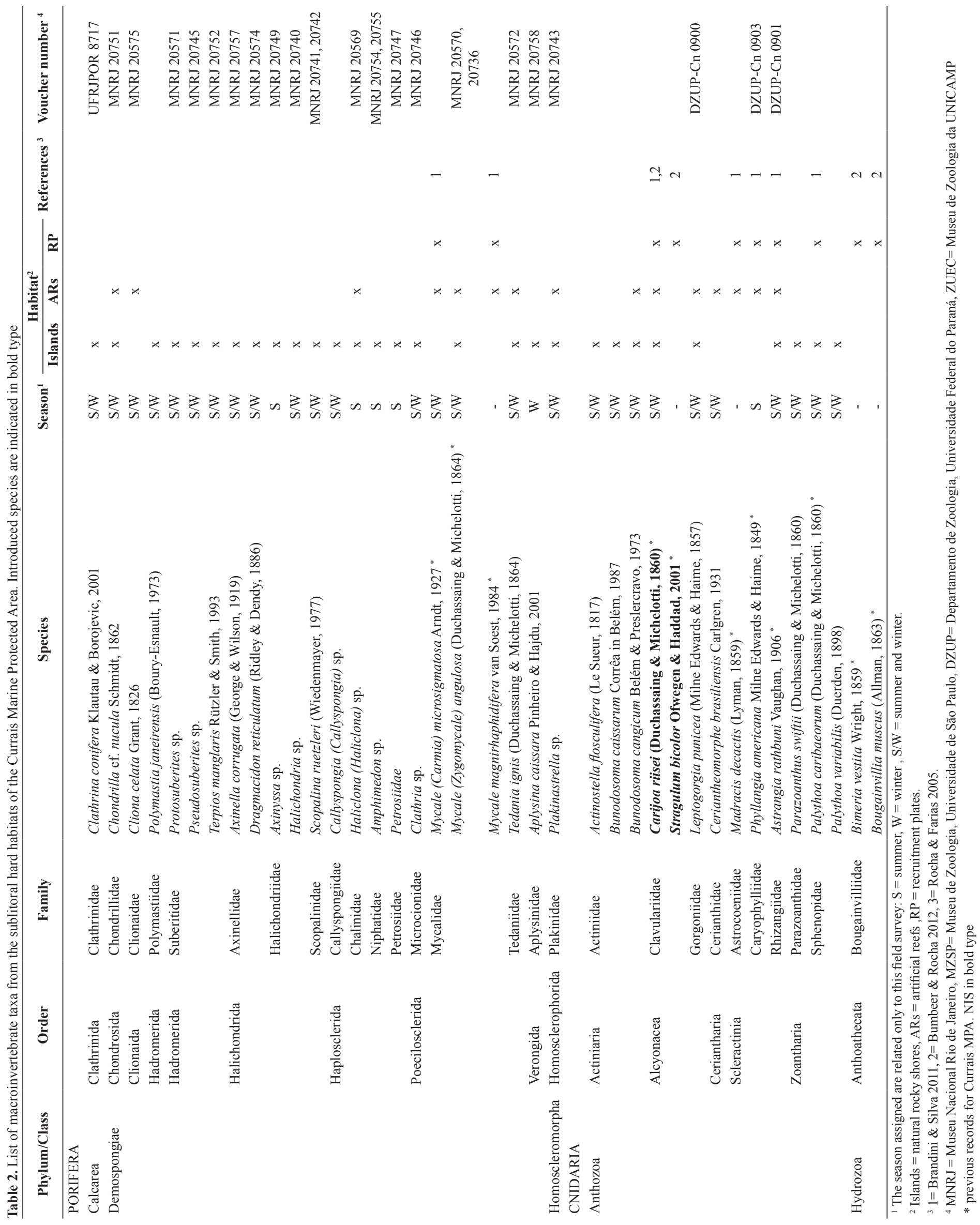




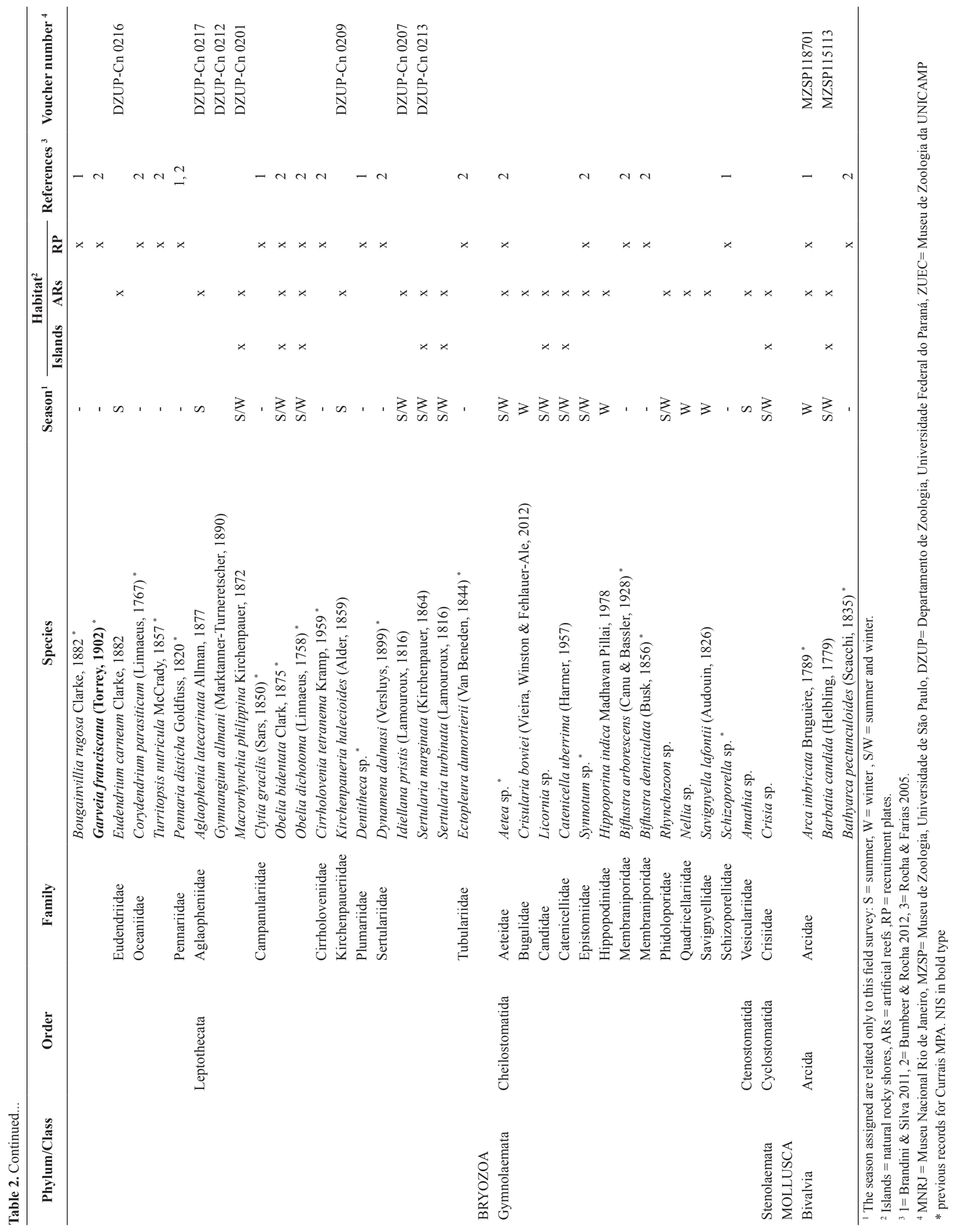




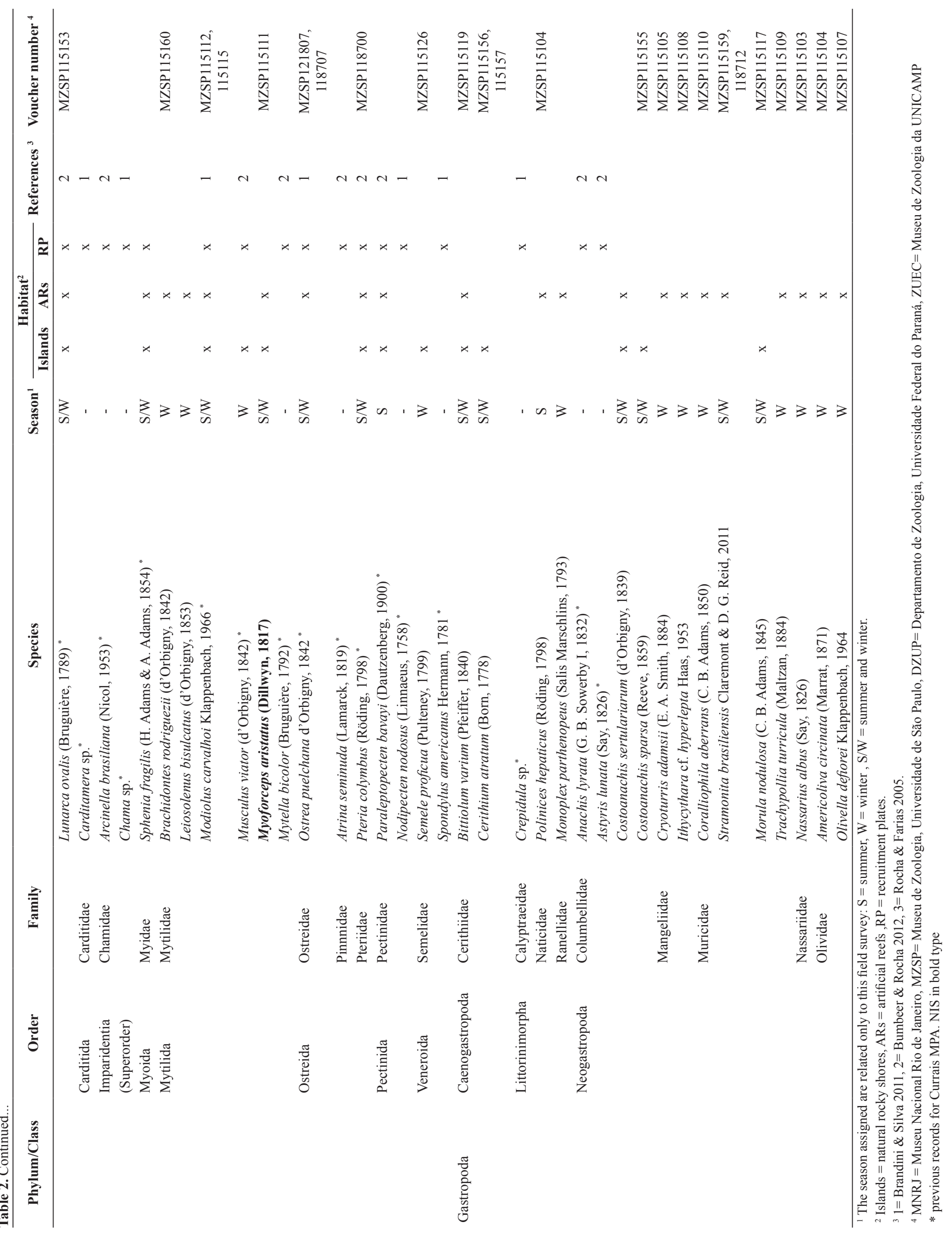




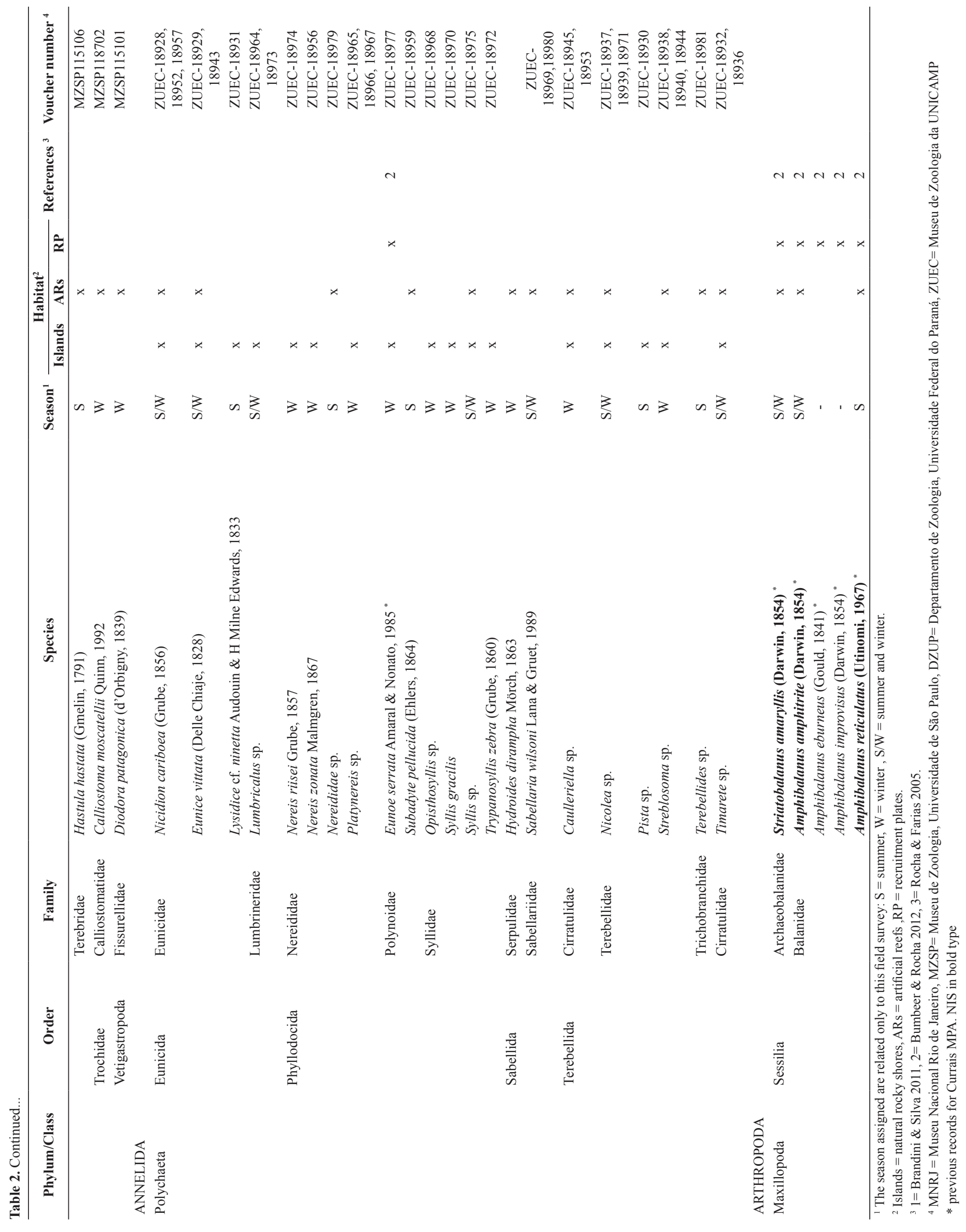




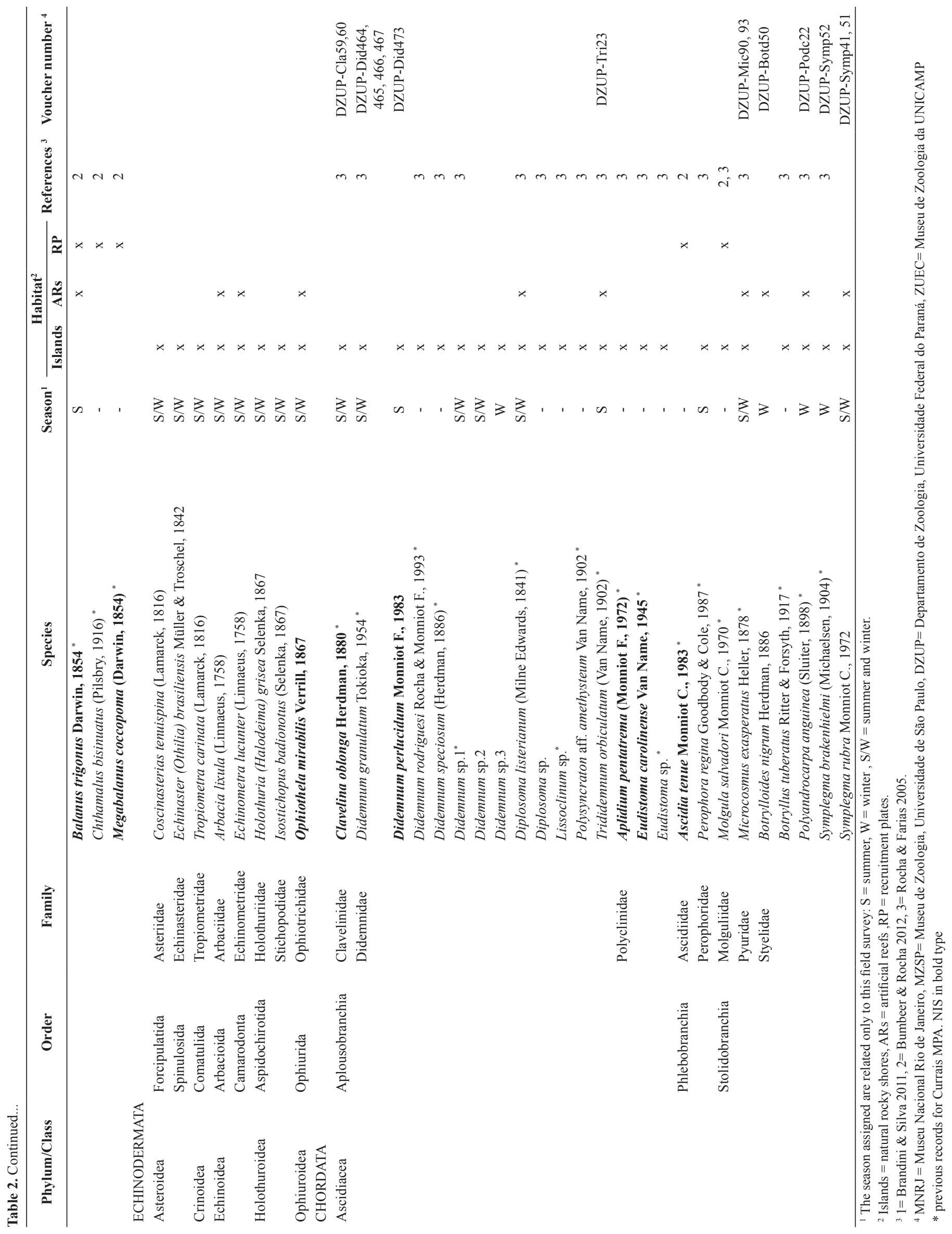




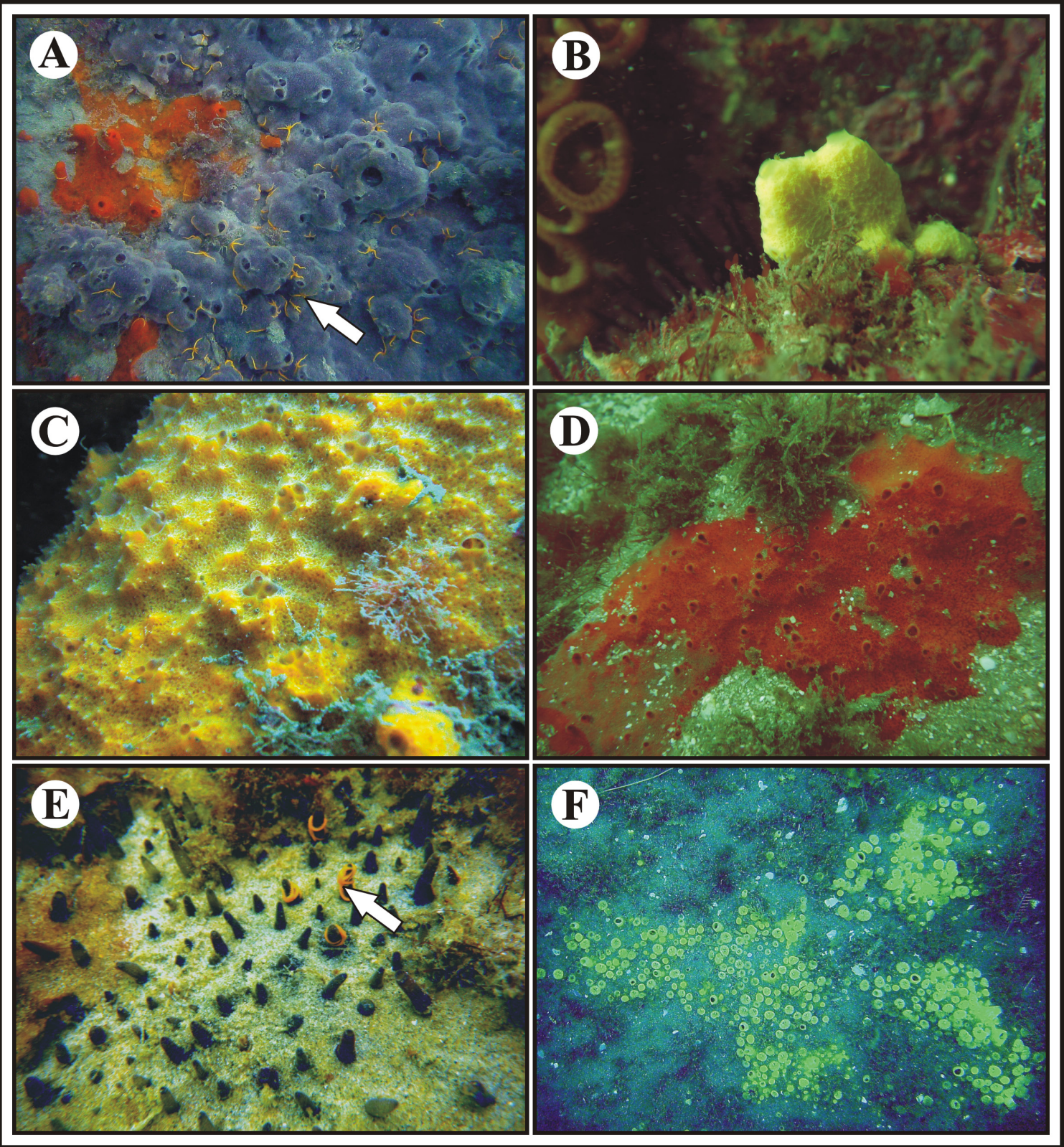

Figure 2. Sponges of Currais MPA: (A) Mycale (Zygomicale) angulosa (blue colony) and Tedania ignis (orange colony), (B) Aplysina cf. caissara, (C) Scopalina ruetzleri, (D) Dragmacidon reticulatum, (E) Polymastia janeirensis, (F) Cliona celata. The arrows indicate the non-indigenous brittle star Ophiothela mirabilis.

$18 \mathrm{~m}$ depth. The maximum depth that we surveyed in the rocky shores was $8 \mathrm{~m}$ and these differences (light, sedimentation) are likely to explain the differences in species composition. Although similar ecological processes act on different surfaces, communities on artificial substrates are known to be very different from those on adjacent natural substrata (Connell \& Glasby 1999, Bulleri \& Chapman 2004). However, that being said, these two types of substrate still had 45 species in common.

Two prior studies at the Currais MPA used recruitment plates to evaluate colonization of invertebrates (Brandini \& Silva 2011, Bumbeer \& Rocha 2012), including time in their survey of species. Those studies found mostly pioneer species, that are likely to be due to propagule supply rather than to the already developed community. This process may also explain the little species overlap between those studies and this (Table 2). Additionally, the former study used plates of the same material as the ARs that were fixed close to the bottom (Brandini \& Silva 2011), while the latter used polyethylene plates suspended in the water column (Bumbeer \& Rocha 2012). Thus, the studies were different with respect to substrate composition, movement and orientation, and these differences are likely to have caused different suit of species reported in each (Glasby \& Connell 2001).

The endangered sea-star Coscinasterias tenuispina is an important species for conservation in Currais MPA (MMA 445/14). In Brazil, this sea-start has a discontinuous distribution, from Bahia to Santa Catarina, and found in Abrolhos (Bahia), Cagarras (Rio de Janeiro) and Arvoredo (Santa Catarina) MPAs, among others. The sea cucumber Isostichopus badionotus (Selenka, 1867) (Figure 4e) was on the Brazilian list of threatened species, but was excluded in the last evaluation (MMA 445/14). This species is classified in the category of least concern by the global IUCN red list, and is abundant in warmer waters of the Caribbean (Toral-Granda et al. 2013).

The remarkable number of new records, and new species, highlights the lack of biodiversity studies in coastal Paraná and many areas of benthic 


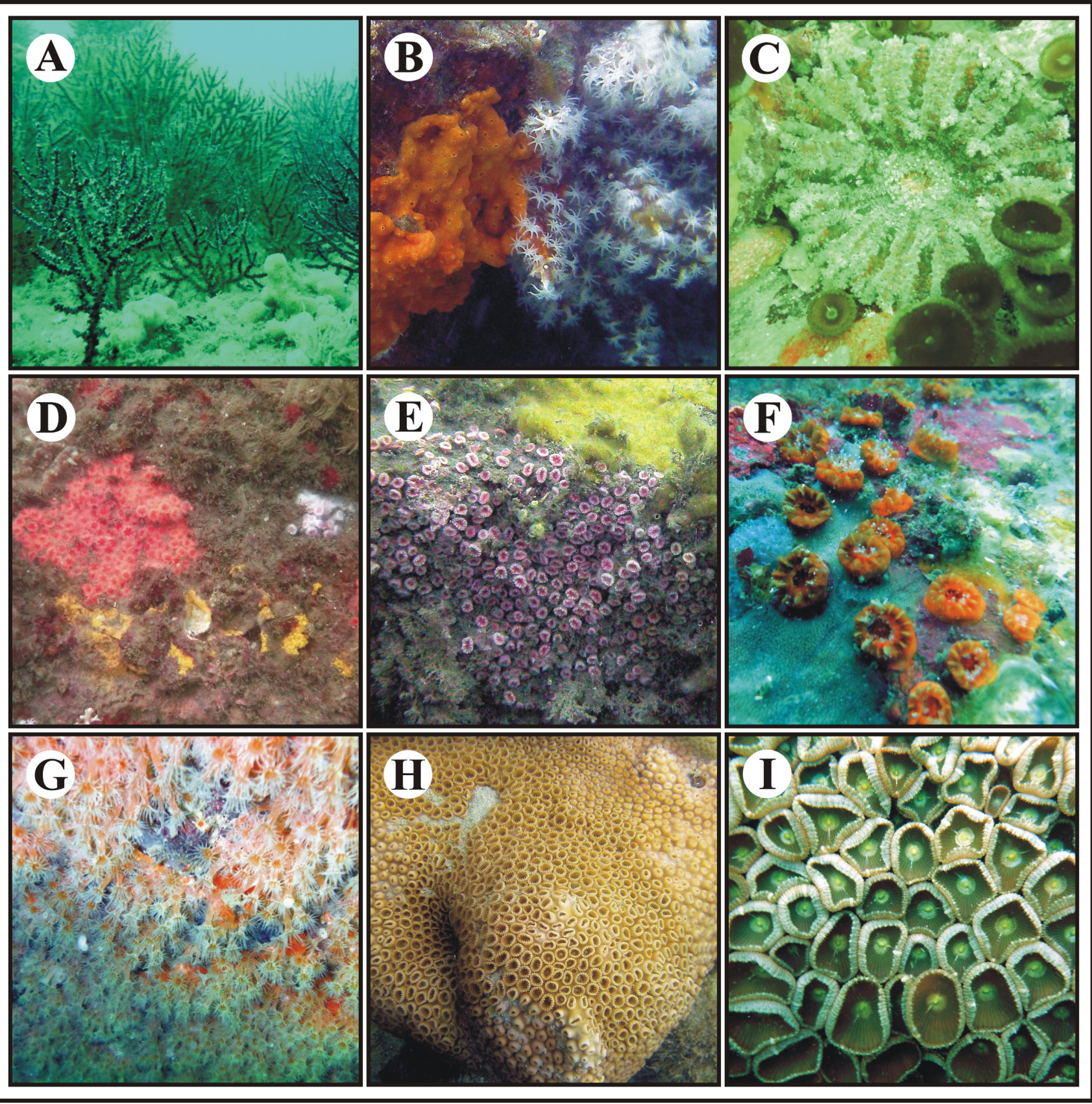

Figure 3. Cnidarians of Currais MPA: (A) Leptogorgia punicea, (B) Carijoa riisei beside the ascidian Didemnum granulatum (orange colony), (C) Actinostella flosculifera, (D) Astrangia rathbuni beside the ascidian Symplegma rubra (yellow colony), (E) Astrangia rathbuni, (F) Phyllangia americana, (G) Parazoanthus swiftii, (H) Palythoa caribaeorum, (I) Palythoa variabilis.

biodiversity on hard substrates remain to be studied, for example, rocky shores bellow depths of $8 \mathrm{~m}$, inventories of cryptic taxonomic groups and vagile benthos other than gastropods, polychaetes and echinoderms. Taxon oriented inventories by specialists are also mandatory for a comprehensive biodiversity survey. For example, a large algal richness was found in a recent study, which found 101 taxa in the Currais Islands (Pellizzari et al. 2014).

The coast of Paraná is in the area of influence of the southern convergence between the cold Malvinas/Falklands current from the south and the warm Brazilian current from the north (Campos et al. 1996, Fernandes \& Brandini 2004), and so the communities are expected to include species from both temperate and tropical waters. Coastal Paraná is also the southern range limit for some species, such as the hydrozoan Kirchenpaueria halecioides
(Alder, 1859), the polychaete Nicidion cariboea (Grube, 1856) and the sponge Amphimedon sp.. It is also the northern range limit for the bivalves Musculus viator (d'Orbigny, 1842) and Brachidontes rodriguezi (d'Orbigny, 1842). Considering the increasing threats to biodiversity, including climate change and ocean warming, that have already caused distributional shifts of species (Sorte et al. 2010), this is an important area to monitor the expansion or constriction of species latitudinal distributions.

Climate change may also modulate the impact and distribution of existing NIS and the establishment of new invasive species (Hellmann et al. 2008). Thus, many NIS found in Currais MPA at low abundances may become invasive, or new species may expand their distribution to Paraná. As has been observed in another MPA located in the southern neighboring state of 

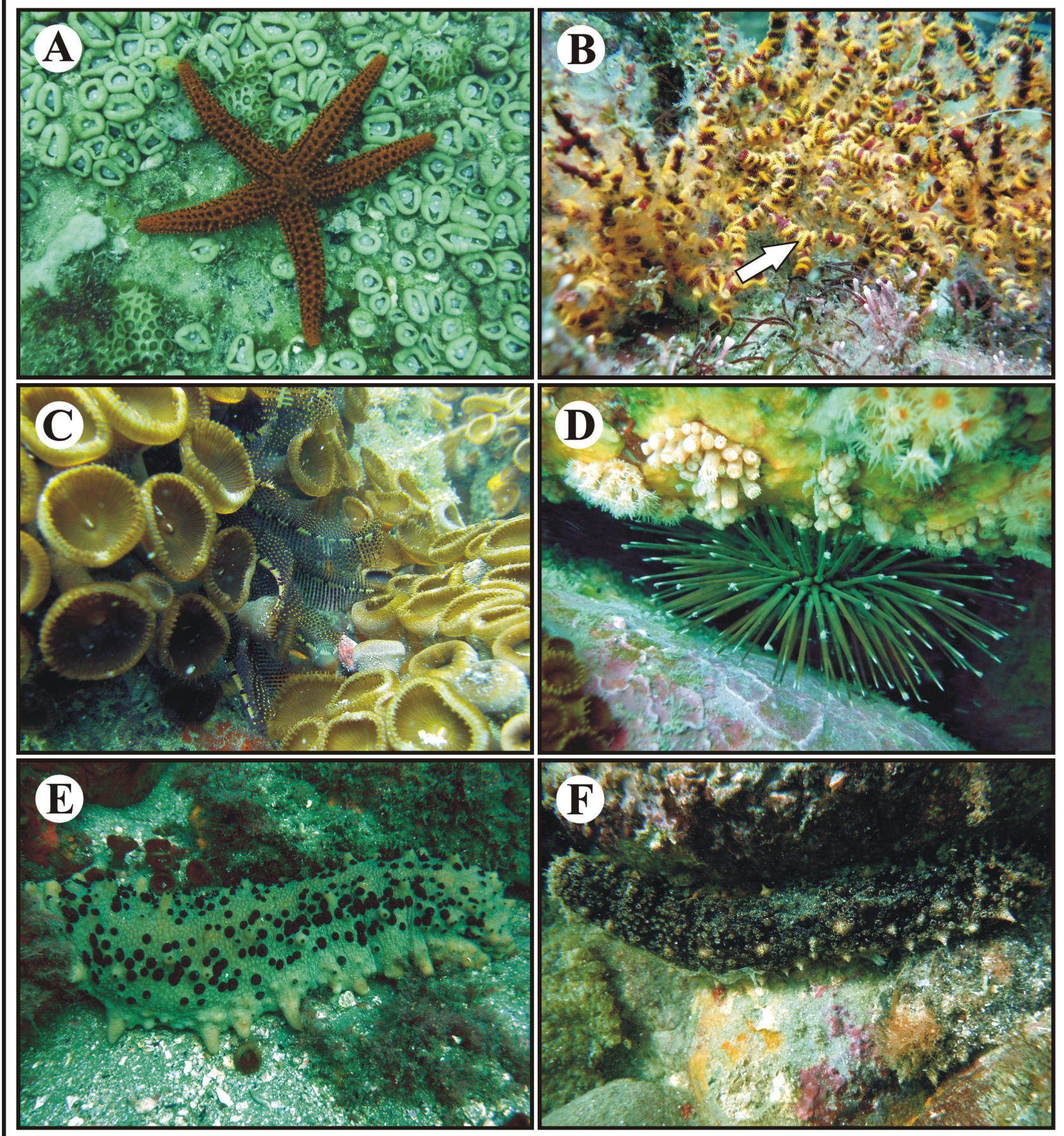

Figura 4. Echinoderms of Currais MPA: (A) Echinaster (Othilia) brasiliensis, (B) Ophiothela mirabilis (arrow) over the gorgonian Leptogorgia punicea, (C) Tropiometra carinata, (D) Arbacia lixula, (E) Isostichopus badionotus, (F) Holothuria (Halodeima) grisea.

Santa Catarina (the Biological Reserve of Arvoredo - see Metri \& Rocha 2008, Bouzon et al. 2012, Cavallari et al. 2012), there are many NIS in the Currais MPA, which endangers the value of this area for biodiversity conservation (Bumbeer \& Rocha 2016).

Coastal Paraná is under the influence of many anthropogenic impacts that favor bioinvasions, such as port-related industries and activities, aquaculture, ships and boat traffic that may contribute to the regional spread of species. Currais MPA is also near freight ship traffic routes as they enter and leave the estuary (Bumbeer and Rocha 2012, 2016). As a consequence, the ophiuroid Ophiothela mirabilis was first reported in
Paraná in 2000 (Hendler et al. 2012) and has now expanded both its range and abundance and occurs abundantly along the entire coast, including Currais MPA (Figures 2 and 4). This species takes advantage of a variety of hosts (Mantellato et al. 2016), yet we still don't know its impact on the native community.

The only invertebrate taxon oriented inventory at Currais MPA (Rocha \& Faria 2005) also provides the opportunity to demonstrate additional changes to community composition. Three of the 12 species found previously but not in this study were probably NIS: the ascidians Aplidium pentatrema (Monniot F., 1972), Eudistoma carolinense Van Name, 1945 and Diplosoma 

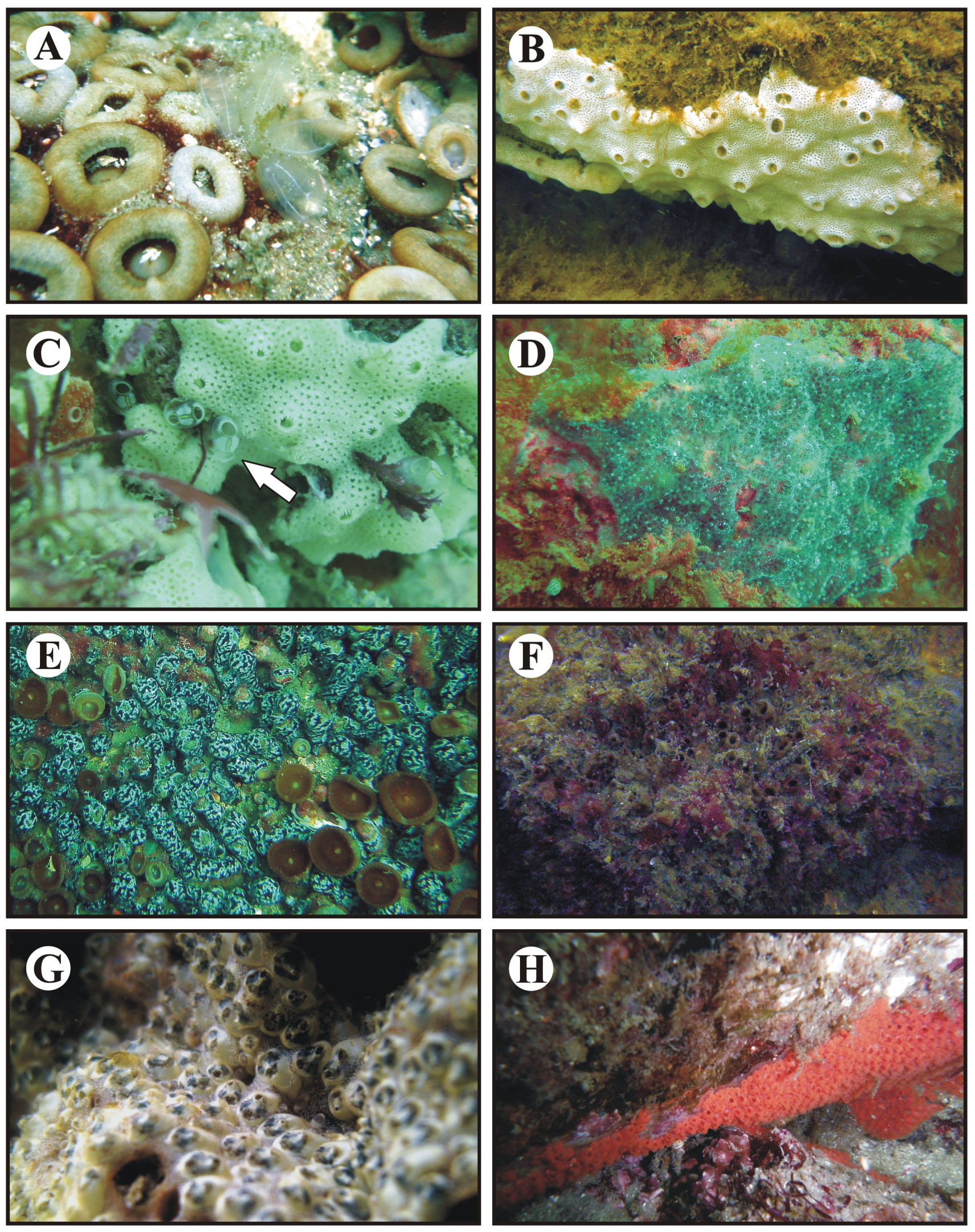

Figure 5. Ascidians of Currais MPA: (A) Clavelina oblonga, (B) Didemnum granulatum, (C) Perophora regina (arrow), Didemnum granulatum (white colony), Didemnum rodriguesi (orange colony), (D) Diplosoma listerianum, (E) Didemnum sp.1 over the zoanthid Palythoa variabilis, (F) Polyandrocarpa anguinea, (G) Symplegma brakenhielmi, (H) Symplegma rubra. 
sp. (Rocha \& Faria 2005). Also, the NIS Ascidia tenue Monniot, 1983 was only found on recruitment plates in 2008/2009 (Bumbeer \& Rocha 2012). Usually, NIS populations fluctuate widely, so the absence of a few in the present study was not that surprising. We also found some first records for NIS in Currais. The species Didemnum perlucidum was first reported in Brazil (in the São Sebastião Channel) in 1995 (Rocha \& Monniot 1995) and found here for the first time for Paraná. This ascidian is now widespread worldwide and a recent study revealed low genetic diversity, including a population from southern Brazil with only one COI haplotype (Dias et al. 2016). This suggests that $D$. perlucidum is introduced. Botrylloides nigrum Herdman, 1886, another new record for Currais MPA, is considered cryptogenic, but its occurrence on anthropogenic substrates (Rocha \& Kremer 2005, Marques et al. 2013) and a new molecular study of global populations (Sheets et al. 2016) suggest that this is also an introduced species in southern Brazil. Symplegma rubra Monniot, 1972 was recorded only within the Paranaguá Estuarine Complex before 2005 (Rocha \& Kremer 2005), yet now it is common in Currais MPA. As $S$. rubra is quite easily encountered and identified, by the large, brightly colored, colonies (Figure $5 \mathrm{~h}$ ), it is unlikely that, if present, it would have passed unnoticed in the 2002/2003 ascidian inventory (Rocha \& Faria 2005). Thus, while probably introduced due to its first records in estuarine areas and recent new occurrences, the lack of genetic information on a global scale leads us to call it cryptogenic.

The new records listed emphasize the importance of continuous monitoring for early detection of new introductions, and suggests that protocols should be established for both early response and control of NIS in the management plan of Currais MPA. Biodiversity inventories should also be encouraged and be carried out by taxonomists. Even a simple list of species can provide a baseline after which changes in the ecosystem can be determined by the disappearance or appearance of species, invasion by NIS, and blooms of opportunistic taxa. Here we provide the first step towards understanding the marine ecosystem of the Currais MPA and towards the development of conservation actions in the southern Brazilian coast.

\section{Acknowledgements}

This study is part of Currais project, which was financed by Fundação Grupo Boticário (0927 20112). We also used data from the Rebimar Program, financed by Petrobras. We are grateful for the support provided by Marbrasil Association and by the Graduate Program in Ecology and Conservation - UFPR, the doctoral scholarship from CAPES to JAB, and a research grant from CNPq to RMR (305201/2014-0). We want to thank Robin Loose for all the assistance in field work, James Roper for the great assistance with English revision and two anonymous reviewers for their contribution. We also thank Leandro Manzoni Vieira (Bryozoa), Maria Angélica Haddad, Ana Carolina Cabral, Sergio Stampar and Maria Eduarda dos Santos (Cnidaria), Luiz Ricardo de Simone and Daniel Cavallari (Mollusca), Kalina Brauko (Polychaeta), João Luís Carraro, Sula Salani, Fernanda Azevedo and Mariana Poleto dos Santos (Porifera) and Isabela Monteiro Neves (Tunicata) who helped with the identification of species.

\section{References}

BOUZON, J.L., BRANDINI, F.P. \& ROCHA, R.M. 2012. Biodiversity of sessile fauna on rocky shores of coastal islands in Santa Catarina, Southern Brazil. Mar. Sci. 2(5):39-47.

BRANDINI, F.P. \& SILVA, A.S. 2011. Epilithic community development on artificial reefs deployed along a cross-shelf environmental gradient off Parana State, Southern Brazil. Braz. J. Oceanogr. 59:43-53.

BRASIL. Lei n ${ }^{\circ} 12.829$, de 20 de junho de 2013. Cria o Parque Nacional Marinho das Ilhas dos Currais, no Estado do Paraná. Available online at: http://www.planalto. gov.br/ccivil_03/_ato2011-2014/2013/lei/112829.htm. Accessed on April 2016.
BULLERI, F. \& CHAPMAN, M.G. 2004. Intertidal assemblages on artificial and natural habitats in marinas on the north-west coast of Italy. Mar. Biol. 145:381-391.

BUMBEER, J.A. \& ROCHA, R.M. 2012. Detection of introduced sessile species on the near shore continental shelf in southern Brazil. Zoologia 29(2):126-134, doi: 10.1590/S1984-46702012000200005.

BUMBEER, J.A. \& ROCHA, R.M. 2016. Invading the natural substrate: a case study in South Brazil. Zoologia 33(1): e20150211.

CAMPOS, E.J.D., LORENZZETTI, J.A., STEVENSON, M.R., STECH, J.L. \& SOUZA, R.B. 1996. Penetration of waters from the Brazil-Malvinas Confluence region along the South American continental shelf up to $23^{\circ} \mathrm{S}$. An. Acad. Bras. Ci. 68:49-58.

CARNIEL, V.L. \& KRUL, R. 2010. Numbers, timing of breeding, and eggs of Kelp Gulls Larus dominicanus (Charadriiformes: Laridae) on Currais Islands in southern Brazil. Rev. Bras. Ornit. 18(3):146-151.

CAVALLARI, D.C., GONÇALVES, E.P. \& AMARAL, V.S. 2012. New occurrences of Myoforceps aristatus (Bivalvia: Mytilidae) in the Brazilian coast. Strombus 19(1/2):23-27.

CONNELL, S.D. \& GLASBY, T.M. 1999. Do urban structures influence local abundance and diversity of subtidal epibiota? A case study from Sydney Harbour, Australia. Mar. Environ. Res. 47:373-387.

DAROS, F.A., BUENO, L.S., VILAR, C.C., PASSOS, A.C. \& SPACH, H.L. 2012. Checklist of rocky reef fishes from the Currais Archipelago and Itacolomis Island, Paraná state, Brazil. Check List 8(3):349-354.

DIAS, P.J., ROCHA, R.M., GODWIN, S., TOVAR-HERNANDEZ, M.A., DELAHOZ, M.V., MCKIRDY, S., LESTANG, P., MCDONALD, J.I., \& SNOW, M. 2016. Investigating the cryptogenic status of the sea squirt Didemnum perlucidum (Tunicata, Ascidiacea) in Australia based on a molecular study of its global distribution. Aquat. Invasions 11(3):239-245.

FÉLIX, F.C. \& HACKRADT, C.W. 2008. Interaction between Rachycentron canadum and Epinephelus itajara on the Paraná coast, Brazil. Coral Reefs 27(3):633.

FÉLIX-HACKRADT, F.C. \& HACKRADT, C.W. 2008. Estudo populacional e monitoramento do mero, Epinephelus itajara (Lichtenstein, 1822), no litoral do Paraná, Brasil. Nat. Conserv. 6(2):31-46.

FERNANDES, L. F. \& BRANDINI, F.P. 2004. Diatom associations in shelf waters off Paraná State, Southern Brazil: annual variation in relation to environmental factors. Braz. J. Oceanogr. 52(1): 19-34, doi: 10.1590/S1679-87592004000100003

GLASBY, T.M. \& CONNELL, S.D. 2001. Orientation and position of substratum have large effects on epibiotic assemblages. Mar. Ecol. Prog. Ser. 214:127-135.

HACKRADT, C.W. \& FÉLIX-HACKRADT, F.C. 2009. Assembléia de peixes associados a ambientes consolidados no litoral do Paraná, Brasil: uma análise qualitativa com notas sobre sua bioecologia. Pap. Avulsos Zool. 49(31):389-403.

HENDLER G., MIGOTTO A.E., VENTURA C.R.R. \& WILK L. 2012. Epizoic Ophiothella brittle stars have invaded the Atlantic. Coral Reefs 31(4): 1005. doi: 10.1007/s00338-012-0936-6

HELLMANN, J.J., BYERS, J.E., BIERWAGEN, B.G. \& DUKES, J.S. 2008. Five potential consequences of climate change for invasive species. Conserv. Biol. 22(3):534-543.

KRUL, R. 2004. Aves marinhas costeiras do Paraná; p. 37-56 In: J.O. Branco (ed.). Aves marinhas e insulares brasileiras: biologia e conservação. Itajaí: Editora da Univali.

LOPES, R.M. 2009 Informe sobre as espécies exóticas invasoras marinhas no Brasil. Brasília, Ministério do Meio Ambiente, Série Biodiversidade 33, 439p.

LORENZI, L. \& BORZONE, C.A. 2009. Variability of the infauna adjacent to rocky formations on the inner continental shelf of Paraná, Brazil. Zool. 26(4):716-724, doi: http://dx.doi.org/10.1590/S1984-46702009000400016

MANTELATTO, M.C., VIDON, L.F., SILVEIRA, R.B., MENEGOLA, C., ROCHA, R.M., CREED, J.C. 2016. Host species of the non-indigenous brittle star Ophiothela mirabilis (Echinodermata: Ophiuroidea): an invasive generalist in Brazil? Mar. Biodivers. Rec. 9(1):8.

MARQUES, A.C., SANTOS A.K., MIGOTTO, A.E., CABRAL, A.C., RIGO, A.P.R., BETTIM, A.L., RAZZOLINI, E.L., CASCON, H.M., BARDI, J., KREMER, L.P., VIEIRA, L.M., BEZERRA, L.E.A., HADDAD, M.A., OLIVEIRAFILHO, R.R., GUTIERRE, S.M.M., MIRANDA, T.P., FRANKLIN-JR, W., ROCHA, R.M. 2013. Rapid assessment survey for exotic benthic species in 
the São Sebastião Channel, Brazil. Lat. Am. J. Aquat. Res. 41:265-285, doi: 10.3856/vol41-issue2-fulltext-6.

MMA. Ministério do Meio Ambiente. Portaria no 445, 17 de dezembro de 2014. "Lista Nacional Oficial de Espécies da Fauna Ameaçadas de Extinção - Peixes e Invertebrados Aquáticos". Available online at: http://www.icmbio.gov.br/ cepsul/images/stories/legislacao/Portaria/2014/p_mma_445_2014_lista peixes_amea\%C3\%A7ados_extin\%C3\%A7\%C3\%A3o_altrd_p_98_2015. pdf. Accessed on April 2016.

METRI, R. \& ROCHA, R.M. 2008. Banco de algas calcárias, um ecossistema rico a ser preservado. Nat. Conserv. 8:8-17.

NOERNBERG, M.A., ANGELOTTI, R., CALDEIRA, G.A. \& SOUSA, A.F.R. 2008. Determinação da sensibilidade do litoral paranaense à contaminação por óleo. Braz. J. Aquat. Sci. Technol. 12(2):49-59.

PELLIZZARI, F., BERNARDI, J., SILVA, E.M., SILVA, M.C., YOKOYA, N.S. 2014. Benthic marine algae from the insular areas of Paraná, Brazil: new database to support the conservation of marine ecosystems. Biota Neotropica 14(2):1-12. doi: http://dx.doi.org/10.1590/1676-060320140615183049.

POSSATTO, F.E., SPACH, H.L., CATTANI, A.P., LAMOUR, M.R., SANTOS, L.O., CORDEIRO, N.M. \& BROADHURST, M.K. 2015. Marine debris in a World Heritage Listed Brazilian estuary. Mar. Poll. Bull. 91(2):548-553, doi: http://dx.doi.org/10.1016/j.marpolbul.2014.09.032.

ROCHA, R.M. \& FARIA, S.B. 2005. Ascidians at Currais islands, Paraná, Brazil: taxonomy and distribution. Biota Neotropica 5:1-20. http://www.biotaneotropica. org.br/v5n2/pt/abstract?article+BN03105022005.
ROCHA, R.M. \& KREMER, L.P. 2005. Introduced ascidians in Paranaguá Bay, Paraná, southern Brazil. Zoologia 22(4):1170-1184.

ROCHA, R.M. \& MONNIOT, F. 1995. Taxonomic and ecological notes on some Didemnum species (Ascidiacea, Didemnidae) from São Sebastião Channel, south-eastern Brazil. Rev. Bras. Biol. 55(4):639-649.

SHEETS, E.A., COHEN, C.S., RUIZ, G.M., ROCHA, R.M. 2016. Investigating the widespread introduction of a tropical marine fouling species. Ecol. Evol. 6(8):2453-2471.

SORTE, C.J.B., WILLIAMS, S.L., \& CARLTON, J.T. 2010. Marine range shifts and species introductions: Comparative spread rates and community impacts. Glob. Ecol. Biogeogr. 19:303-316, doi: 10.1111/j.1466-8238.2009.00519.x

TORAL-GRANDA, T.G., ALVARADO, J.J., HAMEL, J.F., MERCIER, A., BENAVIDES, M. \& ORTIZ, P.E. 2013. Isostichopus badionotus. The IUCN Red List of Threatened Species 2013: e.T180519A1642750. http://dx.doi. org/10.2305/IUCN.UK.2013-1.RLTS.T180519A1642750.en. Accessed 06 April 2016.

Received: 11/08/2016

Revised: 04/09/2016

Accepted: 16/09/2016 